\title{
Understanding Strategies of Anti-Nuclear Movement: A Study of ICAN Memahami Strategi Gerakan Anti-Nuklir:Sebuah Studi Tentang ICAN
}

\section{Mutti Anggitta}

International Relations, BINUS University

email:mutti.anggitta@gmail.com

\begin{tabular}{l} 
Riwayat Artikel \\
\hline Diterima: 22 Oktober 2020 \\
Direvisi: 30 Maret 2021 \\
Disetujui: 6 April 2021 \\
doi: 10.22212/jp.v12i1.1924
\end{tabular}

doi: $10.22212 /$ jp.v12i1.1924

\section{Abstract}

This article argues that the most unique characteristic of the ICAN's activism is its transnational scope, which was made possible by the use of eight strategies by the organization including geostrategic headquarters, internet and technology, government relations, NGOs connection, celebrity spotlight, perfect timing, creativity, and responsiveness. In evaluating the argument, this article provides evidence by employing process-tracing methods and conducting archival analysis to closely examine the historical timeline of important events or moments surrounding the ICAN's activism since its inception in 2007 to the adoption of the Treaty on the Prohibition of Nuclear Weapons in 2017. This article first provides a literature review on social movements against nuclear weapons to provide some background. It then describes how the eight strategies are employed by the ICAN as they are reflected in its transnational activism. It finally notes the five key milestones that are achieved by the organization.

Keywords: Nuclear Weapons; Nuclear Zero; Social Movement; ICAN; Treaty on the Prohibition of Nuclear Weapons.

\section{Abstrak}

Artikel ini berargumen bahwa karakteristik paling unik dari aktivisme ICAN adalah jangkauannya yang bersifat transnasional, yang dicapai berkat penggunaan delapan strategi mencakup letak kantor pusat yang strategis, internet dan teknologi, hubungan dengan pemerintah, jejaring LSM, sorotan selebriti, pemilihan waktu yang tepat, kreativitas, dan kemampuan merespon. Dalam mengevaluasi argumen tersebut, artikel ini memaparkan data dengan menggunakan metode process tracing dan melakukan analisis arsip untuk memeriksa secara detail peristiwa-peristiwa penting seputar aktivisme ICAN sejak didirikan pada 2007 hingga diadopsinya Perjanjian Pelarangan Senjata Nuklir pada 2017. Artikel ini menyediakan tinjauan pustaka tentang gerakan sosial melawan senjata nuklir untuk menjelaskan latar belakang isu ini. Kemudian artikel ini menjelaskan bagaimana delapan strategi tersebut digunakan oleh ICAN, sebagaimana tercermin dalam aktivisme transnasionalnya. Di akhir, artikel ini mengidentifikasi lima pencapaian utama yang diraih oleh ICAN.

Kata Kunci: Senjata Nuklir; Nuclear Zero; Gerakan Sosial; ICAN; Perjanjian Pelarangan Senjata Nuklir. 


\section{The Background}

Nuclear weapons have been a central issue in international politics since their introduction at the global level during World War II. The use of nuclear weapons by the United States on Hiroshima (August 6th, 1945) and Nagasaki (August 9th, 1945) shows that nuclear weapons are very destructive and indiscriminate in nature. In both cities, approximately 50,000-70,000 people immediately died, and 100,000-200,000 people died because of the indirect effects. 1 Nuclear weapons are still the only weapons today that can kill hundreds of thousands of people instantly. The world's stockpile of nuclear weapons reached its peak in 1986 with approximately 70,300 warheads (see Graph 1 below).

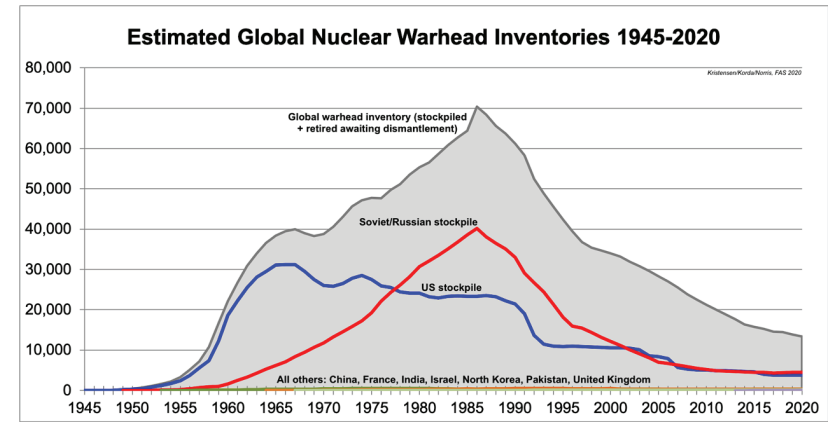

Source: Hans Kristensen and Matt Korda, "Status of World Nuclear Forces"

Graph 1. Estimated Global Nuclear Warhead Inventories 1945-2020

Today, world nuclear forces are much smaller in quantity than during the Cold War. In mid of 2018 , it is estimated that there are only 14,485 warheads remaining (see Graph 2 below). Nuclear weapon states, especially the United States and Russia (the two countries with the most nuclear arsenals), often claim such great reduction as an accomplishment of the arms control agreements. ${ }^{2}$

1 Tom Sauer, Eliminating Nuclear Weapons: The Role of

Missile Defense (London: Hurst, 2011), 5.

2 Hans Kristensen and Matt Korda, "Status of World Nuclear Forces,” accessed on Dec 8th, 2019, https://

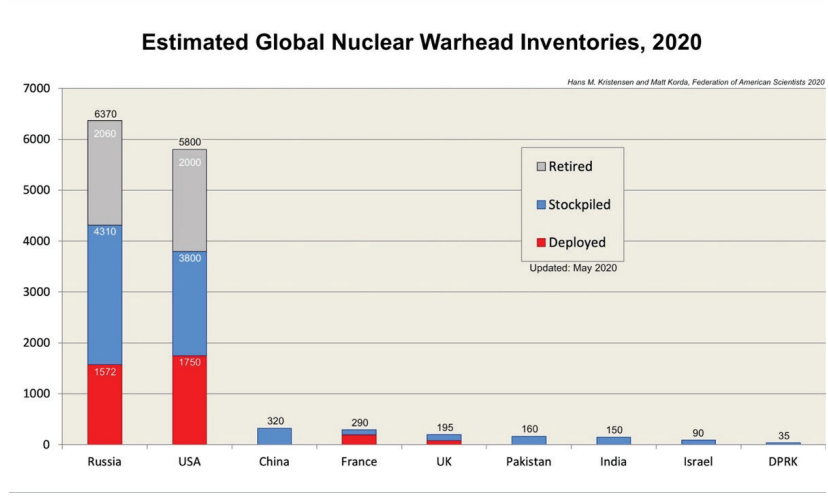

Source: Hans Kristensen and Matt Korda, "Status of World Nuclear Forces"

Graph 2. Estimated Global Nuclear Warhead Inventories 2020

Although the world's combined stockpile of nuclear weapons is now smaller, unfortunately, this does not necessarily mean more peace. In fact, the risks of a nuclear catastrophe today are even higher than during the Cold War. ${ }^{3}$ Such risks include at least four possible scenarios. Firstly, there is a possibility of interstate wars between countries that possess nuclear weapons, especially among those that recently have tense interactions, such as between the United States and North Korea, or the United States and China, or between India and Pakistan. Secondly, there is a possibility of terrorist attacks using nuclear weapons, either by stealing, buying in the black market, developing an improvised nuclear device, or by exploding conventional bombs at nuclear facilities. Thirdly, there is a possibility of nuclear weapons launched because of miscalculation, accident, or cyberattacks. Lastly, there is a possibility of a hidden potential arms race between states with nuclear weapons, which may lead to security dilemmas and then war.

It is true that the exact numbers of nuclear weapons are not open to the public since such data is considered as top national

fas.org/issues/nuclear-weapons/status-world-nuclearforces/

3 Lawrence Freedman, "Frostbitten: Decoding the Cold War, 20 Years Later," Foreign Affairs, Vol. 89, no. 2, (2010): 136-144 
security secret. However, Kristensen and Korda managed to make a careful estimation of the size and composition of nuclear weapon stockpiles based on publicly available data, historical records, and leaks (see Table 1 below). Perkovich and Acton also assert that all nine states with nuclear weapons continue to modernize their nuclear arsenals and are committed to keeping them for the indefinite future. $^{4}$

Despite such modernization, the world still witnessed positive progress toward nuclear disarmament. On July $7^{\text {th }}, 2017$, the Treaty on the Prohibition of Nuclear Weapons (TPNW), sponsored by the International Campaign to Abolish Nuclear Weapons (ICAN), was endorsed by 122 of 193 states in the United Nations. More comprehensive than the Nuclear Non-Proliferation Treaty (NPT), the TPNW prohibits the testing, development, production, acquisition, manufacture, and possession of nuclear weapons. Just three years later, as of October 22 $2^{\text {nd }}, 2020,84$ states have signed the treaty and 47 of them have ratified it. Finally, the treaty came into force on January $22^{\text {nd }}, 2021$, with 86 signatories and 51 state parties in total.

\section{The Puzzle}

This paper does not argue that the ICAN is the sole hero that brought the world together to agree on the TPNW. However, the treaty does mark the significant role of the ICAN. The non-governmental organization (NGO) with transnational networks, which began in 2007, acted as a catalyst for the treaty. That none of the nine states with nuclear weapons signed it yet, does not make such accomplishment less significant. In fact, since the invention of nuclear weapons in the 1950s, the TPNW is the first treaty that globally forbids 4 George Perkovich and James Acton, Abolishing Nuclear Weapons: A Debate, accessed on Dec 8th, 2019, http://carnegieendowment.org/files/ abolishing_nuclear_weapons_debate.pdf nuclear weapons development, production, possession, use, threat of use, and deployment of another state's nuclear weapons on a states party's territory. ${ }^{5}$

The adoption of the TPNW also challenges statements, which assert that the activism of social movement began to decline rapidly since the end of the Cold War. ${ }^{6}$ This paper aims to unravel this discrepancy by answering the question: "How did the ICAN lead the global movements in supporting the goal of negotiating the TPNW from 2007 to 2017?" This paper will specifically examine the ICAN's activism and the means this organization employs in achieving its goal. By doing so, this paper contributes to the academic debates surrounding the topics of civil society and social movements. It specifically contributes to the academic debates on how non-state actors, specifically NGOs act as norm entrepreneurs or advocates to influence the perception of the public and states, and the latter's decisionmaking especially on nuclear weapons issues.

\section{The Argument}

This paper argues that the most unique characteristic of the ICAN's activism is its transnational scope, which was made possible by the use of eight strategies by the organization: geostrategic headquarters, internet and technology, government relations, NGOs connection, celebrity spotlight, perfect timing, creativity, and responsiveness. To evaluate the argument, this paper will provide evidence by employing process-tracing methods and conducting archival analysis to closely examine the historical timeline of important events or moments surrounding the ICAN's activism

5 Daryl Kimball, "Treaty on the Prohibition of Nuclear Weapons a Turning Point," accessed on Dec 8th, 2019, https://www.armscontrol.org/pressroom/2017-10/ arms-control-association-applauds-2017-nobel-peaceprize-winner-ican

6 Ward Wilson, "Why are There No Big Nuke Protests?" Bulletin of the Atomic Scientists, Vol. 71, no. 2, (2015): 50-59 
Table 1. Status of World Nuclear Forces 2020

\begin{tabular}{|c|c|c|c|c|c|}
\hline Country & $\begin{array}{l}\text { Deployed } \\
\text { Strategic }\end{array}$ & $\begin{array}{c}\text { Deployed } \\
\text { Nonstrategic }\end{array}$ & $\begin{array}{c}\text { Reservel } \\
\text { Nondeployed }\end{array}$ & $\begin{array}{c}\text { Military } \\
\text { Stockpile }\end{array}$ & Total Inventory \\
\hline Russia & 1,572 & 0 & 2,740 & 4,312 & 6,372 \\
\hline United States & 1,600 & 150 & 2,050 & 3,800 & 5,800 \\
\hline France & 280 & n.a. & 10 & 290 & 290 \\
\hline China & 0 & $?$ & 320 & 320 & 320 \\
\hline United Kingdom & 120 & n.a. & 75 & 195 & 195 \\
\hline Israel & 0 & n.a. & 90 & 90 & 90 \\
\hline Pakistan & 0 & n.a. & 160 & 160 & 160 \\
\hline India & 0 & n.a. & 150 & 150 & 150 \\
\hline North Korea & 0 & n.a. & 35 & 35 & 35 \\
\hline Total: & $\sim 3,720$ & $\sim 150$ & $\sim 5,630$ & $\sim 9,320$ & $\sim 13,410$ \\
\hline
\end{tabular}

Source: Hans Kristensen and Matt Korda, "Status of World Nuclear Forces"

since its inception in 2007 to the adoption of the TPNW in 2017. This paper will first provide a literature review on social movements against nuclear weapons to provide some background. It will then describe how the eight strategies are employed by the ICAN as they are reflected in its transnational activism. It will finally note the five key milestones that are achieved by the organization.

\section{Literature Review}

Since Hiroshima and Nagasaki, there have been many efforts to minimize the possibility of another nuclear catastrophe. The efforts have been led and fueled by global civil society and are also known as the nuclear weapon disarmament movement. This global movement is a combined effort of millions of people across the world to challenge the reliance of states on nuclear weapons. It evolved along with the Cold War and the arms race between the United States and the Soviet Union in the 1950s. In 1950, the World Peace Council initiated a call for the prohibition of nuclear weapons known as the Stockholm 'Ban the Bomb' petition. Around 500 million people all over the world signed the petition. In 1954, after the United States conducted its first hydrogen bomb test, a grassroots movement against nuclear weapons began to significantly spread across the world, although primarily concentrated in North America, Western Europe, and Japan. The movement includes prominent intellectuals, scientists, pacifists, religious communities, housewives, and students. ${ }^{7}$

Anti-nuclear sentiment grew stronger after prominent figures, such as Norman Cousins (American political journalist), Linus Pauling (American theoretical physical chemist), and Bertrand Russell (British philosopher) joined the movement. Soon the National Committee for a Sane Nuclear Policy and the Committee for Non-Violent Action in the United States, the Campaign for Nuclear Disarmament in the United Kingdom, and the transnational Pugwash group of scientific lobbies, and other peace organizations called for a test ban and an end to the arms race, particularly between the United States and the Soviet Union. ${ }^{8}$ However, they were frequently opposed by political elites. Such opposition seems expected because at that time, supporting campaigns against nuclear weapons would risk accusations of risking national security and electoral defeat. ${ }^{9}$ In the 1960s, hundreds of

7 Lawrence Wittner, The Struggle against the Bomb, Vol. 1 E2 2, (Stanford: Stanford University Press, 1993, 1997)

8 Lawrence Wittner, The Struggle against the Bomb, Vol. 2, (Stanford: Stanford University Press, 1997)

9 Lawrence Freedman, "Nuclear Disarmament: From a 
thousands of people marched on the streets across the United States protesting against nuclear weapons. Two decades later, the number of people in the country opposing nuclear weapons significantly increased, and a petition to freeze the country's nuclear weapons was signed by more than a million people. The United Kingdom, Germany, and other European countries also witnessed mass protests against nuclear weapons in their cities. $^{10}$

In the late 1990s, an extensive academic literature emerged and highlighted the important role of the nuclear disarmament movement. Lawrence Wittner seems to be 'the father' of the studies in this specific field. Among others, his three-volume book, The Struggle Against the Bomb, comprehensively discusses the history of nuclear weapons from the beginning to 2003. His key argument is that the great scale and international reach of the social movement against nuclear weapons restrained world leaders (especially from major powers) from considering nuclear weapons as viable tools of war. He also describes how the activisms led by Communist-sponsored movements differ from the ones led by the non-aligned movement. Moreover, he notes that although sentiment against nuclear weapons exists in almost every country, there is only little transnational interaction. ${ }^{11}$

Another important topic in the academic literature on social movements against nuclear weapons is the movement's influence on policy and how to measure such influence. Jeffrey Knopf in Domestic Society and International Cooperation offers a model of how grassroots

Popular Movement to an Elite Project, and Back Again?" Abolishing Nuclear Weapons: A Debate, accessed on Dec 8th, 2019, http://carnegieendowment.org/files/ abolishing_nuclear_weapons_debate.pdf

10 Ward Wilson, "Why are There No Big Nuke Protests?" Bulletin of the Atomic Scientists, Vol. 71, no. 2, (2015): 50-59.

11 Lawrence Wittner, The Struggle against the Bomb, Vol. 1, 2, E3 3, (Stanford: Stanford University Press, 1993, 1997, 2003) movements against nuclear weapons can pressure political elites into changing policy. He also closely looks at a number of case studies during the Cold War period. ${ }^{12}$ Matthew Evangelista in Unarmed Forces: The Transnational Movement to End the Cold War examines the influence of transnational civil society on Soviet policy. His findings suggest that peace activists could influence the closed Soviet system to move toward policy change. ${ }^{13}$ Other existing academic and policy literatures also explore the possible reasons behind the slow progress of nuclear disarmament. A large body of literature also describes the emergence of nuclear zero as a norm and the role of the global anti-nuclear movement in strengthening the non-proliferation regime.

In terms of social movements in general, not specific to nuclear weapons issues, much literature describes the processes of transnational contention, of mobilization, of action by advocacy movements to take a stand and persuade decision-makers to accept what activists believe to be the right thing. ${ }^{14}$ Various literatures also focus on whether the messages of the campaigns correspond with the local values and the ability of different groups to mobilize. Fewer studies focus on conditions that facilitate successful social movement campaigns. To the best of my knowledge, a detailed exploration of the role of the ICAN in negotiating the TPNW has not been appended in the existing academic literature.

\section{The ICAN: Its Strategies}

This section provides a detailed description of the ICAN's strategies from 2007 to 2017.

12 Jeffrey Knopf, Domestic Society and International Cooperation: The Impact of Protest on US Arms Control Policy, (NY: Cambridge University Press, 1998)

13 Matthew Evangelista, Unarmed Forces: The Transnational Movement to End the Cold War, (Ithaca: Cornell University Press, 1999)

14 Richard Price, "Reversing the Gun Sights: Transnational Civil Society Targets Land Mines," International Organization, 52, no. 3, (1998): 613-644 
Today, the organization is a coalition of 468 NGOs from over 100 states. The description below focuses on the activities that have been taken by the organization and how they are implemented. This section is divided into subsections based on the eight strategies used by the organization.

\section{Geostrategic Headquarters}

On 7 September 2006, a non-partisan federation of national medical groups in 64 countries, known as the International Physicians for the Prevention of Nuclear War (IPPNW), adopted the ICAN as a top priority at its world congress in Helsinki. Two months later, the ICAN set up its first office in Melbourne, Australia. The organization at the time had only three full-time employees and a part-time office temp. Its first campaign took place in February 2007, promoting an African nuclear-weapon-free zone in 13 African countries, and encouraging them to support the negotiations on a global treaty to ban and eliminate nuclear weapons. ${ }^{15}$ Choosing Australia for its first office and Africa as its priority for its first campaign does not seem a coincidence. In fact, it seems that the ICAN intentionally chose both continents as the only two continents without nuclear weapons on their lands or waters, besides Antarctica. This also seems to be one of the ICAN's ways to emphasize the global nature of the threats posed by nuclear weapons although the majority of nuclear weapons are located in the West.

\section{The Internet and Technology}

Two months after its first campaign, in April 2007, the ICAN started using the internet and launched its first international website: icanw.org. It is clear that the ICAN not only understands the importance of spreading its voice against nuclear weapons across the

15 ICAN, "Campaign Milestones 2007," accessed on Dec 8th, 2019, http://www.icanw.org/campaign/ campaign-overview/campaign-milestones-2007/ world, but it also understands the power of the internet. Through the internet, the ICAN also aims to engage youth and the millennial generation who have limited knowledge about the security, humanitarian, and environmental threats posed by nuclear weapons. At the end of the month, on April 30 $30^{\text {th }}, 2007$, the ICAN was launched internationally during the NPT preparatory committee meeting in Vienna, Austria. ${ }^{16}$

On 9 May 2007, the ICAN released a campaign video, sending the world a warning about the ongoing security threats posed by nuclear weapons and advising the public to get involved and take action for a global ban. The video ends with the chant: "Together I can, you can, they can, we can abolish nuclear weapons". ${ }^{17}$ At the second conference on the humanitarian impact of nuclear weapons held in Mexico on February $13^{\text {th }}, 2014$, the ICAN delivers a video statement highlighting the urgency of banning nuclear weapons on the global level in front of government representatives of 146 countries. ${ }^{18}$

ICAN posts its campaign videos on its Vimeo and Youtube accounts. Since its existence until the day the TPNW was adopted, ICAN posted 97 videos on Vimeo and 61 videos on Youtube. They are all different videos (not duplicates), except "No More Hiroshima and Nagasaki: Ban Nuclear Weapons" and "The Nuclear Age in Six Movements" (both are posted on Vimeo and Youtube). Looking at the content of the videos, ICAN seems to take advantage of videos as both marketing and education tools. The videos feature not only speeches or testimonies of important people (such as world leaders, politicians, famous activists, actors, athletes, and the 16 ICAN, “Campaign Milestones 2007," accessed on Dec 8th, 2019, http://www.icanw.org/campaign/ campaign-overview/campaign-milestones-2007/

17 ICAN, "An introduction to ICAN," accessed on Dec 8th, 2019, https://vimeo.com/14537205

18 ICAN, "Campaign Milestones 2011," accessed on Dec 8th, 2019, http://www.icanw.org/campaign/ campaign-overview/campaign-milestones-2011/ 
Pope), but also those of common people who share the same value on nuclear weapons and participated in campaigns against the weapons. The videos also cover a wide range of informative content aimed to raise the awareness of the public. This content includes the basic science of what nuclear weapons are, why they are dangerous, the history of their use, the current world inventory, the diverging positions of various states on the treaty banning the weapons, and the progress of the negotiation process to reach the treaty.

Informative and entertaining videos with a combination of text, image, narration, music back sound, and interesting title get the most views. Although ICAN posted less videos on Youtube (61 videos) than on Vimeo (97 videos), the former has 19 videos with more than 1,000 views, while the latter only has 10 videos with 1,000 views. This is potentially because of the content itself, or because the public is more familiar with Youtube, rather than Vimeo. The ICAN's most viewed video (92,795 views) entitled "It's Time to have the Courage to Ban Nuclear Weapons" is posted on Youtube. This video incorporates both the informative and entertaining features. On the other hand, the ICAN's least viewed video (6 views) is entitled "ICAN Campaigner from Burundi”, posted on Vimeo. The content of this video is just a short testimony of a volunteer in Burundi about a campaign he participated in, with no additional text, image, or other important information.

Besides ICAN, other NGOs devoted to nuclear disarmament issues (such as Global Zero, Greenpeace, the Campaign for Nuclear Disarmament, United for Peace and Justice, the International Fellowship of Reconciliation, and the Women's International League for Peace and Freedom), also use the internet, video, and social media in their campaigns. As Wittner observes, nuclear disarmament organizations use "the new technologies" including mass emails and listservs to reach out to the general public and civil society groups who share the nuclear disarmament norms, and to mobilize them to engage and participate in their campaigns. Moreover, the attractive, informative, and easy to explore websites help these organizations to attract a much larger audience for their mental, physical, and financial supports. The rapid increase in the use of online publications, rather than the "old" print publications, is particularly significant and useful for the organizations. ${ }^{19}$ Similarly, UNIDIR also notes that "the trending" tools of campaigns today are online petitions and meetings, as well as use of social media to raise media coverage, public awareness, and pressure on national decision-makers. ${ }^{20}$

\section{Government Relations}

A year since its first campaign, the ICAN started to establish active interactions with governments. The organization soon developed friendly relations with a number of prominent government officials who shared the same view on nuclear weapon issues. For example, on July 9 ${ }^{\text {th }}, 2008$, Tilman Ruff (the ICAN co-founder) and Akira Kawasaki (a key Japanese member of the ICAN) as nongovernmental representatives, attended the launch of the International Commission on Nuclear Non-Proliferation and Disarmament (ICNND), organized by the Australian and Japanese governments. The main objective of the ICNND is to strengthen international efforts on nuclear non-proliferation and disarmament. ${ }^{21}$ Another example, on June $3^{\text {rd }}$. $4^{\text {th }}, 2014$, several government representatives

19 Lawrence Wittner, "Where is the Nuclear Abolition Movement Today?" Disarmament Forum (UNIDIR Journal) No. 4, (2010): 3-13

20 UNIDIR, "Civil Society and the Conference on Disarmament," accessed on Dec 8th, 2019, https:// www.unidir.org/files/publications/pdfs/civil-societyand-the-conference-on-disarmament-360.pdf

21 ICNND, "About the Commission," accessed on Dec 8th, 2019 from http://www.icnnd.org 
from Malaysia, Thailand, the Philippines, Vietnam, Myanmar, and Mongolia participate in discussions with the ICAN campaigners about their role in prohibiting nuclear weapons and building a civil society movement in their home countries. ${ }^{22}$

Besides networking with current government representatives, the ICAN also reaches out to former or retired government officials. For example, on January $24^{\text {th }}, 2012$, the ICAN launches a petition supported and signed by former prime ministers, foreign ministers, defense ministers, judges, military commanders, and hundreds of other prominent Australians. The petition urges strong leadership for a global ban against nuclear weapons and specifically an end to Australia's reliance on the United States' nuclear weapons extended security umbrella. ${ }^{23}$

\section{NGOs Connection}

Fully aware of the nature of opportunities and challenges surrounding its activism, the ICAN reaches out to many other NGOs and establishes both formal and informal relations with them. The ICAN also works closely together with them within various platforms, not only when the organization is having its main events, but also when other NGOs are having their own main agenda. For example, a month after its first campaign, in March 2007, Mayors for Peace formally joined the ICAN as an international partner organization. Mayors for Peace is a global network of more than 5,000 local governments (city leaders) in 150 states, and led by the mayors of Hiroshima and Nagasaki. ${ }^{24}$

The ICAN is wise and smart for connecting

22 ICAN, "Campaign Milestones 2014," accessed on Dec 8th, 2019, http://www.icanw.org/campaign/ campaign-overview/campaign-milestones-2014/

23 ICAN, "Campaign Milestones 2012," accessed on Dec 8th, 2019, http://www.icanw.org/campaign/ campaign-overview/campaign-milestones-2012/

24 ICAN, "Campaign Milestones 2007," accessed on Dec 8th, 2019, http://www.icanw.org/campaign/ campaign-overview/campaign-milestones-2007/ itself with the Mayors for Peace because the latter is a highly respected network in the global movement to abolish nuclear weapons. This NGO aims to create a more peaceful world, one that is free from the threats posed by nuclear weapons. Therefore, it works to increase support from local communities for the complete global elimination of nuclear weapons by 2020. Its key principle is that no city deserves to be the target of a nuclear attack, and that the only effective way to eliminate the nuclear threats is to ban the weapons and abolish them without further delay. ${ }^{25}$

In October 2007, Physicians for Global Survival (the Canadian affiliate of the IPPNW) and other Canadian disarmament groups also formed a nationwide coalition of the ICAN partner organizations. ${ }^{26}$ Moreover, on September $10^{\text {th }}, 2012$, the Israeli Disarmament Movement, in partnership with the ICAN and the Japanese Peace Boat, organized a historic tour of Israel by four Hibakusha (nuclear bomb survivors) from Hiroshima. The four Hibakusha came to Israel to share their testimonies on the devastating human consequences of nuclear weapons with Holocaust survivors. The Japanese Government selected the four Hibakusha as "Special Communicators for a Nuclear-Free World". ${ }^{27}$ In addition, on January $26^{\text {th }}, 2013$, the ICAN organized a conference in Turkey on a world without nuclear weapons and other types of weapons of mass destruction. The conference was attended by other NGOs, such as Greenpeace and the Global Peace and Justice Coalition. ${ }^{28}$

25 Mayors for Peace, "2020 Vision," accessed on Dec 8th, 2019, http://www.mayorsforpeace.org/english/ecbn/ index.html

26 ICAN, "Campaign Milestones 2007," accessed on Dec 8th, 2019, http://www.icanw.org/campaign/ campaign-overview/campaign-milestones-2007/

27 Peace Boat, "Hiroshima in Israel: Hibakusha Give Testimony during Historic Visit," accessed on Dec 8th, 2019 from http://peaceboat.org/english/?page=view\& $\mathrm{nr}=60 \&$ type $=21 \&$ menu $=62$

28 ICAN, "Campaign Milestones 2013," accessed on Dec 8th, 2019, http://www.icanw.org/campaign/ campaign-overview/campaign-milestones-2013-2/ 
Furthermore, on March $2^{\text {nd }}-3^{\text {rd }}, 2013$, the ICAN organized a major civil society forum in Oslo. In this forum, more than 500 campaigners from 70 states gathered to discuss ways to improve global efforts to get negotiations started on a global treaty prohibiting nuclear weapons. ${ }^{29}$ On September $26^{\text {th }}, 2014$, to mark the international day for the total elimination of nuclear weapons, the ICAN organized Nuclear Abolition Day. The Nuclear Abolition Day was established by the United Nations General Assembly in 2013 to enhance "public awareness and education about the threat posed to humanity by nuclear weapons and the necessity for their total elimination". ${ }^{30}$ In celebrating the Nuclear Abolition Day, ICAN's partner organizations around the world also organized various activities, including film screenings, music concerts, lectures, and petitions to promote a global nuclear weapons ban. ${ }^{31}$

\section{The Celebs' Spotlight}

The ICAN also takes advantage of the fame of celebrities in getting the world's attention. In this case, celebrities are not limited to the ones from the Hollywood industries, but also famous and influential individuals on the international level. For example, on April $29^{\text {th }}$, 2007, Nobel laureate Jody Williams (an American political activist known for her work in banning anti-personnel landmines), endorsed the ICAN. She connects the issues of nuclear weapons to those of anti-personnel mines: "In a world of increasing nuclear dangers, it's time for an international campaign to abolish nuclear weapons. We are told by some governments that a nuclear weapons convention is premature and unlikely. Don't believe it. We were told the same

29 ICAN, "Campaign Milestones 2013.”

30 ICAN, "Nuclear Abolition Day 2014 National Activities," accessed on Dec 8th, 2019, http://www. icanw.org/campaign-news/7342/

31 ICAN, "Campaign Milestones 2014," accessed on Dec 8th, 2019, http://www.icanw.org/campaign/ campaign-overview/campaign-milestones-2014/ thing about a mine ban treaty". 32 Moreover, on August 28 ${ }^{\text {th }}$, 2007, Hans Blix (former Director General of the International Atomic Energy Agency) endorsed the ICAN through a video message on Youtube, where he notes that the existence of thousands of nuclear weapons in the world today is an inconvenient truth of our time. ${ }^{33}$

On April 28 ${ }^{\text {th }}$, 2008, His Holiness the 14th Dalai Lama sends a statement supporting the ICAN: "A nuclear weapons convention is feasible, necessary and increasingly urgent. I can imagine a world without nuclear weapons, and I support ICAN." 34 On October 24 ${ }^{\text {th }}$, 2008, Ban Ki-moon (former United Nations Secretary General) joined the call for a ban, urging states to implement current legal obligations by negotiating a nuclear weapons agreement. He considered the model agreement prepared by the ICAN as a good point of departure for negotiations. ${ }^{35}$ On March 3 $3^{\text {rd }}$ 2009, Herbie Hancock (an American Jazz legend) endorsed the ICAN through a video message on Youtube: "Nuclear weapons are the biggest threat to all living beings on our planet. Because I cannot tolerate the existence of these appalling, humanity-destroying weapons, I wholeheartedly support ICAN." 36

Moreover, in March 2010, Ian Chappell (Australian Cricket star) endorsed the ICAN: "If we want our legacy to future generations to be one we're proud of, then pushing for a world that is free from nuclear weapons would have an enormously positive effect. I support the work of ICAN." ${ }^{37} \mathrm{On}$

32 ICAN, "Campaign Milestones 2007," accessed on Dec 8th, 2019, http://www.icanw.org/campaign/ campaign-overview/campaign-milestones-2007/

33 ICAN, "Dr Hans Blix endorses ICAN," accessed on Dec 8th, 2019, https://www.youtube.com/watch?v=cy PeIWanNZU\& feature=youtu.be $\% 2 \mathrm{C}+340+$ views

34 ICAN, "Campaign Milestones 2008," accessed on Dec 8th, 2019, http://www.icanw.org/campaign/ campaign-overview/campaign-milestones-2008/

35 ICAN, "Campaign Milestones 2008."

36 ICAN, Herbie Hancock supports ICAN," accessed on Dec 8th, 2019, https://www.youtube.com/ watch?v=TTWggJAflYE

37 ICAN, "Campaign Milestones 2010," accessed on Dec 8th, 2019, http://www.icanw.org/campaign/ 
June $29^{\text {th }}, 2011$, in an opinion article penned for the ICAN, Desmond Tutu (South African Nobel Peace Prize-winning anti-apartheid and human rights activist) called for an "end to nuclear evil". He also urged governments to start negotiations without further delay on a global agreement banning nuclear weapons through a video on Youtube. ${ }^{38}$

On May 12 $12^{\text {th }}$ 2016, the ICAN and Ploughshares Fund (a public grant-making foundation supporting the initiatives to prevent the spread and use of nuclear weapons) held a press conference in Geneva with Michael Douglas (a United Nations Messenger of Peace as well as an Academy Award-winning actor and producer). He praises the ICAN for its work to emphasize the catastrophic humanitarian consequences of nuclear weapons. ${ }^{39} \mathrm{He}$ also states that he "found religion" in the anti-nuclear weapon cause after the Three Mile Island accident in 1979 , which is coincidentally within only days of the opening of his movie called "The China Syndrome", which is also dealt with an emergency at a nuclear facility. ${ }^{40}$

\section{Timing is Key}

Since the very beginning of its activisms, the ICAN pays close attention to timing to get a wider group of participants, support, and news coverage. The organization takes advantage of important or popular events or moments that are regularly celebrated by nations or even specific communities. For example, on April 1 1st, 2007, which is April campaign-overview/campaign-milestones-2010/

38 ICAN, "Arch Desmond Tutu talks about the need to ban nuclear weapons \#goodbyenukes," accessed on Dec 8th, 2019 from https://www.youtube.com/ watch?v=TOMYQPY9T6A

39 ICAN, "Campaign Milestones 2016," accessed on Dec 8th, 2019, http://www.icanw.org/campaign/ campaign-overview/campaign-milestones-2016/

40 Tom Miles, "Michael Douglas Urges Obama to Think of His Legacy at Hiroshima," accessed on Dec 8th, 2019, https://www.reuters.com/article/ us-nuclear-disarmament-douglas/michael-douglasurges-obama-to-think-of-his-legacy-at-hiroshimaidUSKCNOY32PY
Fools' Day, the ICAN smartly used the Day to highlight the foolishness of states with nuclear weapons as well as states with nuclear weapons security umbrella for relying on such weapons as a deterrence tool. On this April Fools' Day, the ICAN organized a rally and peace music concert with approximately 10,000 people involved. ${ }^{41}$ On August $6^{\text {th }}, 2008$, the ICAN campaigners organized vigils, exhibitions, and many other events across the world to commemorate the Hiroshima and Nagasaki tragedies. ${ }^{42}$ Even on April 5 ${ }^{\text {th }}, 2009$, the ICAN also organized peace rallies to mark Palm Sunday, the Sunday before Easter.

In terms of events related to international governmental affairs, on May 15, 2009 , the ICAN delegates attended the NPT preparatory committee meeting at the United Nations Headquarters in New York City. They called on all the NPT member states to fulfill their commitment to pursue nuclear weapons disarmament in good faith. ${ }^{43}$ In the following year, on May $2^{\text {nd }}, 2010$, the ICAN activists with approximately more than 15,000 protesters from around the world marched through the streets in New York City to support the negotiation on a global treaty prohibiting nuclear weapons. On the same day, campaigners from Japan presented 26 million petition signatures to Sergio Duarte (United Nations Disarmament High Commissioner) on the eve of the NPT Review Conference. The petition called for concrete work to begin now on a global ban on nuclear weapons. ${ }^{44}$

During another Hiroshima and Nagasaki Day commemoration, on August $6^{\text {th }}, 2012$,

41 ICAN, “Campaign Milestones 2007," accessed on Dec 8th, 2019, http://www.icanw.org/campaign/ campaign-overview/campaign-milestones-2007/

42 ICAN, "Campaign Milestones 2008," accessed on Dec 8th, 2019, http://www.icanw.org/campaign/ campaign-overview/campaign-milestones-2008/

43 ICAN, "Campaign Milestones 2009," accessed on Dec 8th, 2019, http://www.icanw.org/campaign/ campaign-overview/campaign-milestones-2009/

44 ICAN, "Campaign Milestones 2010," accessed on Dec 8th, 2019, http://www.icanw.org/campaign/ campaign-overview/campaign-milestones-2010/ 
the ICAN published a comprehensive study on the catastrophic effects of nuclear weapons on human health, societies, and the environment in general. ${ }^{45}$ Also, on July $6^{\text {th }}-7^{\text {th }}$, 2015, on the 60th anniversary of the famous Russell-Einstein manifesto (which was issued in 1955 during the Cold War and highlighted the threats posed by nuclear weapons and called for world leaders to work on peaceful resolutions), the ICAN campaigners gathered in London to discuss the principles that should support a global treaty prohibiting nuclear weapons and the diplomatic process needed to achieve it. ${ }^{46}$

\section{Utility and Creativity}

The ICAN campaigners are also creative, producing campaign tools that are unique and useful in educating the public about the dangers of nuclear weapons. For example, in November 2008, the ICAN published a booklet for primary and secondary school students called "Learn Peace". The booklet includes activities, including holding a Model United Nations (MUN) debate, role-playing a nuclear crisis and describing a nuclear blast, as well as folding paper cranes. ${ }^{47}$ On April 19, 2010, the ICAN United Kingdom launched an animation on nuclear weapons disarmament, which highlights the uselessness of nuclear weapons in tackling any global security challenges today, such as global warming and terrorism. On August $6^{\text {th }}$, 2010, students from Hiroshima took part in an initiative led by the ICAN in creating the world's longest video chain letter, pushing leaders from states with nuclear weapons to abolish their nuclear

45 ICAN, "Campaign Milestones 2012," accessed on Dec 8th, 2019, http://www.icanw.org/campaign/ campaign-overview/campaign-milestones-2012/

46 ICAN, "Campaign Milestones 2015," accessed on Dec 8th, 2019, http://www.icanw.org/campaign/ campaign-overview/campaign-milestones-2015/

47 ICAN, "Campaign Milestones 2008," accessed on Dec 8th, 2019, http://www.icanw.org/campaign/ campaign-overview/campaign-milestones-2008/ weapon stockpiles. Not only students from Hiroshima, but people around the world were also encouraged to upload their own video "pleas" on Youtube. ${ }^{48}$

Furthermore, in December 2010, the ICAN released its first detailed analysis of government policies concerning a nuclear weapons convention. The study shows that 142 states supported the immediate commencement of negotiations on a ban, whereas 21 states were 'lukewarm', and 29 states were 'skeptical'. 49 On September $16^{\text {th }}$, 2011, the ICAN campaigners from around the world contributed to a video stressing that the elimination of nuclear weapons is everybody's business. On September $17^{\text {th }}$, 2011, approximately more than 130 people from across the globe, including many people from Africa and the Middle East, participated in the ICAN's first international conference in Geneva. ${ }^{50}$

On November $4^{\text {th }}, 2011$, the ICAN Norway released an inspirational animation that encourages people to work to outlaw nuclear weapons. On March 5 ${ }^{\text {th }}$, 2012, the ICAN launched a major report called "Don't Bank on the Bomb". This study focuses on global investments in companies with services and products related to the development of nuclear weapons, including nuclear weapons materials and technology. The ICAN campaigners around the world put pressure on their financial institutions at their home countries to end their support for the nuclear weapons industries. ${ }^{51}$

On Nuclear Abolition Day, June 2nd, 2012, the ICAN released a video highlighting

48 ICAN, "Campaign Milestones 2010," accessed on Dec 8th, 2019, http://www.icanw.org/campaign/ campaign-overview/campaign-milestones-2010/

49 ICAN, "Campaign Milestones 2010."

50 ICAN, "Campaign Milestones 2011," accessed on Dec 8th, 2019, http://www.icanw.org/campaign/ campaign-overview/campaign-milestones-2011/

51 Don't Bank on the Bomb, "About the Report," accessed on Dec 8th, 2019, https://www.dontbankonthebomb. com/2018_about-the-report/ 
that 10 seconds is all it takes to create a humanitarian catastrophe. Only 10 seconds is also the time required for leaders to sign the treaty prohibiting nuclear weapons. A few days later, on June $10^{\text {th }}, 2012$, Nasser Burdestani (an ICAN campaigner) launched an Arabic version of "Learn Peace" (the booklet for primary and secondary school students). The translation is part of efforts to spread education on nuclear weapons to schoolchildren outside the Western hemisphere as well. In July 2012, activists in Sweden launched the ICAN with an interesting event where doctors offered blood-pressure tests to show that we need to prevent heart attacks as well as nuclear attacks. Another interesting and important event is that in September 2012, the ICAN campaigners from Hiroshima sent 1,000 hand-folded paper cranes to every single president and prime minister around the world. In return, they requested a message of support from them for a global ban on nuclear weapons. ${ }^{52}$

\section{Responsiveness}

The ICAN is also responsive and following the news about what is happening in the world, especially on events or matters related to nuclear weapons issues. For example, on May 25 , 2009, North Korea announced that it successfully conducted its second underground nuclear weapon test. The ICAN condemned the test by issuing a statement and calling on all states that have not yet done so to ratify the Comprehensive Nuclear Test Ban Treaty (CTBT)..$^{53}$ On June 5th, 2010 , following the NPT Review Conference, the ICAN held its first global day of action. On this day, thousands of people participated in 50 simultaneous events in 25 states as part of the ICAN's global day of action, with an aim

52 ICAN, "Campaign Milestones 2012," accessed on Dec 8th, 2019, http://www.icanw.org/campaign/ campaign-overview/campaign-milestones-2012/

53 ICAN, "Campaign Milestones 2009," accessed on Dec 8th, 2019, http://www.icanw.org/campaign/ campaign-overview/campaign-milestones-2009/ to deliver a message: "begin negotiations now on a nuclear weapons convention." ${ }^{4}$ A year later, on June $25^{\text {th }}, 2011$, the ICAN even held a bigger event during its second global day of action for a treaty banning nuclear weapons, consisting of 140 simultaneous events taking place in 25 states. ${ }^{55}$

\section{The ICAN's Five Key Achievements}

Since its inception in 2007, the ICAN has achieved a lot. The description of the eight strategies above also indirectly highlights many of the organization's achievements. However, besides of course the adoption of the TPNW itself, this paper notes five key milestone achievements. Firstly, on February $22^{\text {nd }}$ $26^{\text {th }}$, 2016, groundbreaking talks began on developing a new legal instrument to achieve and maintain a world without nuclear weapons at the United Nations Office in Geneva. In that meeting, the ICAN proposed the elements that should be included in the legal instrument (the TPNW). The organization argues that the same rationale used to ban biological weapons, chemical weapons, anti-personnel landmines, and cluster munitions (their cruel and indiscriminate harm to civilians) should be applied to nuclear weapons. It also attempts to stigmatize nuclear weapons by framing them as inherently immoral and a violation of international law, as a counter to the perception that the weapons are symbols of power or deterrence to enhance national security. ${ }^{56}$

Secondly, on the first day the TPNW was open for signatures, on September $20^{\text {th }}$, 2017,50 states signed the treaty and 3 of them

54 ICAN, “Campaign Milestones 2010," accessed on Dec 8th, 2019, http://www.icanw.org/campaign/ campaign-overview/campaign-milestones-2010/

55 ICAN, "Campaign Milestones 2011," accessed on Dec 8th, 2019, http://www.icanw.org/campaign/ campaign-overview/campaign-milestones-2011/

56 ICAN, "Campaign Milestones 2016," accessed on Dec 8th, 2019, http://www.icanw.org/campaign/ campaign-overview/campaign-milestones-2016/ 
ratified it. As of the first week of December 2018, a total of 69 states signed the treaty and 19 of them ratified it. Compared to other treaties, such as the conventions on biological and chemical weapons, the CTBT, and even the NPT, these numbers set a record pace for the speed with which it is moving towards becoming legally binding-when the TPNW has 50 states parties. ${ }^{57}$ The ICAN hoped to achieve 50 ratifications by the end of 2018 .

Thirdly, on October $6^{\text {th }}, 2017$, the 2017 Nobel Peace Prize was awarded to the ICAN. Beatrice Fihn (the ICAN's Executive Director) challenged the world leaders during her Nobel lecture by stating, "It is not irrational to think nuclear states can disarm. It is a necessity." 58 In response, the United States through the State Department reiterated its position: "This treaty will not make the world more peaceful, will not result in the elimination of a single nuclear weapon, and will not enhance any state's security." 59 The Russian government did not make a comment. Also, as a protest against the winner, the United States, together with the United Kingdom and France did not send a representative to the award ceremony. ${ }^{60}$

Another two interesting observations are: 1) different from the official British stance on the TPNW, Jeremy Corbyn (the British opposition Labor party leader) congratulated the ICAN, and 2) India, a state with nuclear weapons sent a bouquet of tulips to the ICAN, suggesting that to a certain extent the country supports the treaty. ${ }^{61}$ Despite the

57 ICAN, "19 States Party \& 69 Signatories: the Nuclear Ban Treaty Gains Support at Record Pace,” accessed on Dec 8th, 2019, https://www.icanw.org/19_states_ party_69_signatories_the_nuclear_ban_treaty_gains_ support_at_record_pace

58 Eric Schlosser, "The Growing Dangers of the New Nuclear-Arms Race," accessed on Dec 8th, 2019, https://www.newyorker.com/news/news-desk/thegrowing-dangers-of-the-new-nuclear-arms-race

59 Eric Schlosser, "The Growing Dangers of the New Nuclear-Arms Race."

60 Eric Schlosser, "The Growing Dangers of the New Nuclear-Arms Race."

61 Jamey Keaten and Mark Lewis, "Group Opposing Nuclear Weapons Wins Nobel Peace Prize,” accessed absence of official support from states with nuclear weapons, the Nobel Peace Prize still gave new momentum for the ICAN and its allies to achieve ratification of the TPNW by at least 50 states. Such ratification does not only make the treaty become legally binding for the member states, but in the long term, it will also put states with nuclear weapons in an uncomfortable position of being outliers.

Fourthly, on November $10^{\text {th }}$ 2017, Pope Francis supports the TPNW, which means he changed the Catholic Church's position on nuclear weapons. The Vatican had long opposed the use of nuclear weapons in war and promoted nuclear disarmament, but it did recognize their deterrence values in preventing war. Pope Francis regards nuclear weapons as "senseless from even a tactical standpoint," criticizes their "catastrophic humanitarian and environmental effects," and "firmly condemned" the threat of their use as well as their very possession. ${ }^{62}$

Fifthly, the 2018 annual report on Don't Bank on the Bomb shows significant progress. According to the report, 23 financial institutions based in the United States, the United Kingdom, Italy, Norway, Denmark, the Netherlands, Sweden, and Australia have adopted, implemented, and published a policy that comprehensively prevents any financial involvement in nuclear weapon producing companies. There are also another 40 financial institutions that have taken some steps to exclude nuclear weapon companies from their investments, but whose policy is not all-inclusive in preventing all types of financial

on Dec 8th, 2019, https://www.apnews.com/26f35c8a beea49ce931e82f0e29b7d5b

62 Pope Francis, "Address of His Holiness Pope Francis to Participants in the International Symposium on Prospects for a World Free of Nuclear Weapons and for Integral Disarmament," accessed on Dec 8th, 2019, http://w2.vatican.va/content/francesco/ en/speeches/2017/november/documents/papafrancesco_20171110_convegno-disarmointegrale. html 
involvement with nuclear weapon industries. ${ }^{63}$

\section{Conclusion}

This paper has argued that the most unique characteristic of the ICAN's activism is its transnational scope, which was made possible by the use of eight strategies by the organization: geostrategic headquarters, internet and technology, government relations, NGOs connections, celebrity spotlight, perfect timing, creativity, and responsiveness. Among these eight strategies, the use of internet and technology as well as NGOs connections are the two key strategies that appear to play a greater role in helping the ICAN to achieve its goals. By using the internet and technology, including websites and videos, the ICAN achieved at least three important accomplishments in its activism: spreading its message and voice against nuclear weapons across the world; educating the youth and millennials about nuclear weapons and engaging them in its campaigns against nuclear weapons; and advising the public in general to take action to push their governments to support for a global ban on nuclear weapons.

By reaching out to and making friends with the established and respected NGOs that share a common value on nuclear weapons, the ICAN achieved two main accomplishments: gathering support from many other NGOs and working together with them; conducting its activities transnationally (in many countries and at the same time), such as the Nuclear Abolition Day, which attracted the media attention globally. Learning from the case of the ICAN, despite its focus on nuclear weapons issues, the eight strategies in general are also applicable for other $\mathrm{NGOs}$ with different goals. Particularly for NGOs with transnational or global scope or goals, the two key strategies (the use of internet and technology as well as NGOs connections) are definitely essential tools for their activism.

This paper also has noted the five key milestones that are achieved by the ICAN, including: 1) the organization's proposal of the elements that should be included in the TPNW; 2) the TPNW set a record pace for the speed with which it is moving towards becoming a law; 3) the 2017 Nobel Peace Prize was awarded to the ICAN, which gave new momentum for the organization and its allies to achieve 50 ratifications of the TPNW; 4) Pope Francis altered the view of the Vatican on nuclear weapons to support the TPNW; and 5) the latest Don't Bank on the Bomb report shows significant progress pressuring financial institutions to end their support for the nuclear weapons industries.

The description of the role of the ICAN in promoting the negotiation of the TPNW in this paper suggests that social movements matter because they are essential in creating political pressures on states to achieve concrete progress on a global treaty against nuclear weapons. It also confirms and complements the history of social movements and civil society in confronting nuclear weapons policies, which has been very well documented by Lawrence Wittner and many other scholars in this field, as discussed above. Finally, developing a causal mechanism on how social movements may cause states to change their policies on nuclear weapons-related issues is beyond the scope of this paper. However, by describing the ICAN's activities, strategies, networks, and current achievements, this paper has provided an exploratory study for future research, which has objective to specifically develop causal relationships or to explain the effectiveness of social movements. 


\section{BIBLIOGRAPHY}

Don't Bank on the Bomb. "About the Report." Accessed on Dec 8th, 2019. https://www. dontbankonthebomb.com/2018_aboutthe-report/

Don't Bank on the Bomb. "2018 Report." Accessed on Dec 8th, 2019. https://www. dontbankonthebomb.com/wpcontent/ uploads/2018/10/2018_Report_web.pdf

Evangelista, Matthew. Unarmed Forces: The Transnational Movement to End the Cold War. Ithaca: Cornell University Press, 1999

Francis, Pope. "Address of His Holiness Pope Francis to Participants in the International Symposium on Prospects for a World Free of Nuclear Weapons and for Integral Disarmament." Accessed on Dec 8th, 2019. http://w2.vatican.va/content/ francesco/en/speeches/2017/november/ documents/papa-francesco_20171110_ convegno-disarmointegrale.html

Freedman, Lawrence. "Frostbitten: Decoding the Cold War, 20 Years Later."

Foreign Affairs, Vol. 89, no. 2, (2010): 136144

Freedman, Lawrence. "Nuclear Disarmament: From a Popular Movement to an Elite Project, and Back Again?" In Abolishing Nuclear Weapons: A Debate, edited by George Perkovich and James Acton. Accessed on Dec 8th, 2019. http:// carnegieendowment.org/files/abolishing_ nuclear_weapons_debate.pdf

ICAN. "Campaign Milestones 2007." Accessed on Dec 8th, 2019. http://www. icanw.org/campaign/campaign-overview/ campaign-milestones-2007/
ICAN. "An introduction to ICAN." Accessed on Dec 8th, 2019. https://vimeo. com/14537205

ICAN. "Campaign Milestones 2011." Accessed on Dec 8th, 2019. http://www. icanw.org/campaign/campaign-overview/ campaign-milestones-2011/

ICAN. "Campaign Milestones 2014." Accessed on Dec 8th, 2019. http://www. icanw.org/campaign/campaign-overview/ campaign-milestones-2014/

ICAN. "Campaign Milestones 2012." Accessed on Dec 8th, 2019. http://www. icanw.org/campaign/campaign-overview/ campaign-milestones-2012/

ICAN. "Campaign Milestones 2007." Accessed on Dec 8th, 2019. http://www. icanw.org/campaign/campaign-overview/ campaign-milestones-2007/

ICAN. "Campaign Milestones 2013." Accessed on Dec 8th, 2019. http://www. icanw.org/campaign/campaign-overview/ campaign-milestones-2013-2/

ICAN. "Nuclear Abolition Day 2014 National Activities." Accessed on Dec 8th, 2019. http://www.icanw.org/campaignnews/7342/

ICAN. "Campaign Milestones 2014." Accessed on Dec 8th, 2019. http://www. icanw.org/campaign/campaign-overview/ campaign-milestones-2014/

ICAN. "Dr Hans Blix endorses ICAN." Accessed on Dec 8th, 2019. https://www. youtube.com/watch? $\mathrm{v}=$ cyPeIWanNZU\& $\mathrm{f}$ eature $=$ youtu.be $\% 2 \mathrm{C}+340+$ views

ICAN. "Campaign Milestones 2008." Accessed on Dec 8th, 2019. http://www. icanw.org/campaign/campaign-overview/ campaign-milestones-2008/

ICAN. Herbie Hancock supports ICAN." Accessed on Dec 8th, 2019. https://www. 
youtube.com/watch?v=TTWggJAflYE

ICAN. "Campaign Milestones 2010.” Accessed on Dec 8th, 2019. http://www. icanw.org/campaign/campaign-overview/ campaign-milestones-2010/

ICAN. "Arch Desmond Tutu talks about the need to ban nuclear weapons \#goodbyenukes." Accessed on Dec 8th, 2019. https://www.youtube.com/ watch?v=TOMYQPY9T6A

ICAN. "Campaign Milestones 2016." Accessed on Dec 8th, 2019. http://www. icanw.org/campaign/campaign-overview/ campaign-milestones-2016/

ICAN. "Campaign Milestones 2009." Accessed on Dec 8th, 2019. http://www. icanw.org/campaign/campaign-overview/ campaign-milestones-2009/

ICAN. "Campaign Milestones 2015." Accessed on Dec 8th, 2019. http://www. icanw.org/campaign/campaign-overview/ campaign-milestones-2015/

ICAN. "19 States Party \& 69 Signatories: the Nuclear Ban Treaty Gains Support at Record Pace." Accessed on Dec 8th, 2019. https://www.icanw.org/19_states_ party_69_signatories_the_nuclear_ban_ treaty_gains_support_at_record_pace

ICNND. "About the Commission." Accessed on Dec 8th, 2019. http://www.icnnd.org

Keaten, Jamey, and Mark Lewis. "Group Opposing Nuclear Weapons Wins Nobel Peace Prize." Accessed on Dec 8th, 2019. https://www. a p n ews.com / 26 f 35 c 8 a b e e a 49 ce931e82f0e29b7d5b

Kimball,Daryl.2017. "TreatyontheProhibition of Nuclear Weapons a Turning Point." Accessed on Dec 8th, 2019. https://www. armscontrol.org/pressroom/2017-10/ arms-control-association-applauds-2017nobel-peace-prize-winner-ican

Knopf, Jeffrey. Domestic Society and International Cooperation: The Impact of Protest on US Arms Control Policy. NY: Cambridge University Press, 1998

Kristensen, Hans, and Matt Korda. "Status of World Nuclear Forces." Accessed on Dec 8th, 2019. https://fas.org/issues/nuclearweapons/status-world-nuclear-forces/

Mayors for Peace. "2020 Vision." Accessed on Dec 8th, 2019. http://www. mayorsforpeace.org/english/ecbn/index. html

Miles, Tom. "Michael Douglas Urges Obama to Think of His Legacy at Hiroshima." Accessed on Dec 8th, 2019. https:// www.reuters.com/article/us-nucleardisarmament-douglas/michael-douglasurges-obama-to-think-of-his-legacy-athiroshima-idUSKCNOY32PY

Peace Boat. "Hiroshima in Israel: Hibakusha Give Testimony during Historic Visit." Accessed on Dec 8th, 2019. http:// peaceboat.org/english/? page $=$ view\& $n r=6$ o\& type $=21 \&$ menu $=62$

Perkovich, George, and James Acton. Abolishing Nuclear Weapons: A Debate. Accessed on Dec 8th, 2019. http:// carnegieendowment.org/files/abolishing_ nuclear_weapons_debate.pdf

Price, Richard. "Reversing the Gun Sights: Transnational Civil Society Targets Land Mines.” International Organization, 52, no. 3, (1998): 613-644

Sauer,Tom. Eliminating Nuclear Weapons: The Role of Missile Defense. London: Hurst, 2011

Schlosser, Eric. "The Growing Dangers of the New Nuclear-Arms Race," accessed on Dec 
8th, 2019. https://www.newyorker.com/ news/news-desk/the-growing-dangers-ofthe-new-nuclear-arms-race

UNIDIR. "Civil Society and the Conference on Disarmament," Accessed on Dec 8th, 2019. https://www.unidir.org/files/ publications/pdfs/civil-society-and-theconference-on-disarmament-360.pdf

Wilson, Ward. "Why are There No Big Nuke Protests?" Bulletin of the Atomic Scientists, Vol. 71, no. 2, (2015): 50-59

Wittner, Lawrence. "Where is the Nuclear Abolition Movement Today?"

Disarmament Forum (UNIDIR Journal) No. 4, (2010): p. 3-13

Wittner, Lawrence. The Struggle against the Bomb (Vol. 3). Toward Nuclear Abolition: A History of the World Nuclear Disarmament Movement, 1971-Present. Stanford: Stanford University Press, 2003

Wittner, Lawrence. The Struggle against the Bomb (Vol. 2). Resisting the Bomb: A History of the World Nuclear Disarmament Movement, 1954-1970. Stanford: Stanford University Press, 1997

Wittner, Lawrence. The Struggle against the Bomb (Vol. 1). One World or None: A History of the World Nuclear Disarmament Movement Through 1953. Stanford: Stanford University Press, 1993 


\section{Appendix 1}

\begin{tabular}{|c|c|c|c|}
\hline No. & Title of Video & Views & Source \\
\hline 1 & ICAN at the Australian parliament & 100 & https://vimeo.com/218749999 \\
\hline 2 & Senator Singh on banning nuclear weapons & 67 & https://vimeo.com/217947125 \\
\hline 3 & Protest at the Australian Parliament to Ban the Bomb! & 82 & https://vimeo.com/210705210 \\
\hline 4 & Campaign highlights of 2016 & 465 & https://vimeo.com/195919685 \\
\hline 5 & How to dismantle an atomic bomb & 257 & https://vimeo.com/191466168 \\
\hline 6 & $\begin{array}{l}\text { Anthony Albanese MP urges Australia to join nuclear ban } \\
\text { negotiations }\end{array}$ & 87 & https://vimeo.com/190945262 \\
\hline 7 & UN votes to outlaw nuclear weapons in 2017 & 498 & https://vimeo.com/190658954 \\
\hline 8 & $\begin{array}{l}\text { Open Letter delivery to the Foreign Minister: ban nuclear } \\
\text { weapons! }\end{array}$ & 87 & https://vimeo.com/188925609 \\
\hline 9 & ICAN media update October 142016 & 171 & https://vimeo.com/187461682 \\
\hline 10 & ICAN calls for ban on nuclear weapons & 64 & https://vimeo.com/187187466 \\
\hline 11 & DSC_1167 & 52 & https://vimeo.com/187126103 \\
\hline 12 & It's our time to make history & 831 & https://vimeo.com/184228452 \\
\hline 13 & $\begin{array}{l}\text { Australia seeks to block negotiations for a ban on nuclear } \\
\text { weapons }\end{array}$ & 177 & https://vimeo.com/179474232 \\
\hline 14 & $\begin{array}{l}\text { The pathway towards a treaty banning nuclear weapons, and } \\
\text { progress so far }\end{array}$ & 135 & https://vimeo.com/166214676 \\
\hline 15 & Public and parliamentary support for a ban & 73 & https://vimeo.com/166209776 \\
\hline 16 & The urgent need for a treaty banning nuclear weapons & 75 & https://vimeo.com/165888027 \\
\hline 17 & A ban on nuclear weapons would enhance the security of all & 23 & https://vimeo.com/165883346 \\
\hline 18 & Medical organizations unite for a ban on nuclear weapons & 21 & https://vimeo.com/165883327 \\
\hline 19 & $\begin{array}{l}\text { Increasing understanding on the humanitarian impact of } \\
\text { nuclear weapons }\end{array}$ & 55 & https://vimeo.com/165294743 \\
\hline 20 & Black Mist White Rain - Tour Highlights & 141 & https://vimeo.com/165237774 \\
\hline 21 & Karina Lester - Black Mist White Rain & 51 & https://vimeo.com/165237342 \\
\hline 22 & Increased transparency with respect to nuclear arsenals & 58 & https://vimeo.com/165124496 \\
\hline 23 & Rose Lester - Black Mist White Rain & 39 & https://vimeo.com/164264955 \\
\hline 24 & Abacca Anjain-Maddison - Black Mist White Rain & 82 & https://vimeo.com/164262328 \\
\hline 25 & Sue Coleman-Haseldine - Black Mist White Rain & 102 & https://vimeo.com/164260103 \\
\hline 26 & $\begin{array}{l}\text { Daniel explains what is happening at the Open Ended } \\
\text { Working Group }\end{array}$ & 180 & https://vimeo.com/158177476 \\
\hline 27 & $\begin{array}{l}\text { Ambassador Lomonaco of Mexico explain why we need a } \\
\text { ban on nuclear weapons }\end{array}$ & 73 & https://vimeo.com/157442503 \\
\hline 28 & $\begin{array}{l}\text { Ambassador O'brian of Ireland talks about the role of civil } \\
\text { society }\end{array}$ & 46 & https://vimeo.com/157442363 \\
\hline 29 & $\begin{array}{l}\text { Ambassador Kmentt of Austria discuss why we need to fill the } \\
\text { legal gap on nuclear weapons }\end{array}$ & 74 & https://vimeo.com/157442180 \\
\hline 30 & Beatrice Fihn at the open-ended working group & 255 & https://vimeo.com/157381942 \\
\hline 31 & Israeli disarmament campaigner Sharon Dolev & 71 & https://vimeo.com/157380279 \\
\hline 32 & Merry Xmas! & 75 & https://vimeo.com/149883523 \\
\hline 33 & Melissa Parke MP on nuclear disarmament & 28 & https://vimeo.com/146208526 \\
\hline 34 & $\begin{array}{l}\text { No more Hiroshimas, No more Nagasakis: Ban nuclear } \\
\text { weapons! }\end{array}$ & 9,419 & https://vimeo.com/135355477 \\
\hline 35 & The Nuclear Age in Six Movements & 1,746 & https://vimeo.com/134159000 \\
\hline 36 & ICAN Campaigners Meeting, London, 6-7 July 2015 & 158 & https://vimeo.com/133511272 \\
\hline 37 & Ban nuclear weapons (goodbyenukes) & 327 & https://vimeo.com/130861928 \\
\hline 38 & Ban Nuclear Weapons & 66 & https://vimeo.com/130852104 \\
\hline 39 & \#ALittleMoreAction (To ban nuclear weapons) (1) & 126 & https://vimeo.com/130847583 \\
\hline 40 & How to fold a paper crane & 411 & https://vimeo.com/130843123 \\
\hline 41 & We are the ones we have been waiting for & 131 & https://vimeo.com/125953505 \\
\hline 42 & It's time to take control: it's time to ban nuclear weapons! & 67 & https://vimeo.com/124795660 \\
\hline 43 & Campaigners spotlight: Josefin & 41 & https://vimeo.com/113790204 \\
\hline 44 & Campaigner spotlight: Jesus & 62 & https://vimeo.com/113779630 \\
\hline 45 & Campaigner spotlight: Benjamin & 21 & https://vimeo.com/113779629 \\
\hline 46 & Campaigners spotlight: Kenny & 43 & https://vimeo.com/113779628 \\
\hline
\end{tabular}


Sequence 011

Thomas Nash

Thomas Nash (double post, same as above)

We just love to be campaigners!

BANg Game Changers say: Thank you!

BANg Campaigner from Colombia

ICAN Campaigner from Switzerland

ICAN Campaigner from Burundi

ICAN Campaigner from Costa Rica

Hector ICAN Mexico

Magnus ICAN Network Coordinator

Robert (1)

Ira

Eric Schlosser

Patricia Lewis

Beatrice Finn

Londoners say ban nuclear weapons

Think outside the bomb. Ban nuclear weapons $\quad 1,244$

Dutch Nuclear Video $\quad 272$

Ban Nuclear Weapons $\quad 3,079$

We Can $\quad 2,075$

Bombs no More! $\quad 240$

Nuclear weapons $\quad 829$

The Million Pleas campaign $\quad 175$

Why do we need a treaty to abolish nuclear weapons? $\quad 2,132$

The role of the UN

95

Nuclear weapons in the headlines $\quad 381$

Hiroshima plea

Kate Dewes on activism

Rob Green on deterrence

Million Pleas

Rhetoric versus reality

Ban Ki-moon's message to ICAN

1,228 https://vimeo.com/113779627

https://vimeo.com/107224612

https://vimeo.com/106839717

https://vimeo.com/104834606

https://vimeo.com/104308239

https://vimeo.com/99326141

https://vimeo.com/99238026

https://vimeo.com/96062985

https://vimeo.com/96061776

https://vimeo.com/86812134

https://vimeo.com/86747906

https://vimeo.com/86638904

https://vimeo.com/86527410

https://vimeo.com/86527409

https://vimeo.com/86527407

https://vimeo.com/86522011

https://vimeo.com/86522010

https://vimeo.com/86445904

https://vimeo.com/86435861

https://vimeo.com/86435860

https://vimeo.com/86435858

https://vimeo.com/86433511

https://vimeo.com/85815012

https://vimeo.com/85815011

https://vimeo.com/85815010

https://vimeo.com/85815009

https://vimeo.com/85814775

https://vimeo.com/70534676

https://vimeo.com/67610144

https://vimeo.com/50508327

https://vimeo.com/31772910

https://vimeo.com/30113179

https://vimeo.com/28966614

https://vimeo.com/24710883

https://vimeo.com/23994767

https://vimeo.com/21963975

https://vimeo.com/19887561

https://vimeo.com/18037122

https://vimeo.com/16722084

https://vimeo.com/15585096

https://vimeo.com/15580834

https://vimeo.com/15416765

https://vimeo.com/14537205

https://vimeo.com/14533015

https://vimeo.com/14532530

https://vimeo.com/12368596

https://vimeo.com/12298405

https://vimeo.com/11047167

https://vimeo.com/10939049

https://vimeo.com/10285583

https://vimeo.com/goodbyenukes

https://www.youtube.com/ watch?v=8rlhq88Mm-4

https://www.youtube.com/ watch?v=K7GiNIgV1nE

https://www.youtube.com/ watch?v=L72XKY60L6U 
No more Hiroshimas, No more Nagasakis: Ban nuclear weapons!

102 The Nuclear Age in Six Movements

15,006

ICAN Campaigners Meeting, London, 6-7 July 2015

672

It's time for change. It's time to ban nuclear weapons!

511

105 Vale Tom Uren

Highlights from the Vienna Conference on the Humanitarian Impact of Nuclear Weapons

ICAN statement at the Vienna Conference on the

Humanitarian Impact of Nuclear Weapons

108 Thank you campaigners!

Australian nuclear test survivor speaks in Vienna

It's time to have the courage to ban nuclear weapons

Jody Williams on how the Mine Ban Treaty was achieved \#goodbyenukes

Arch Desmond Tutu talks about the need to ban nuclear weapons \#goodbyenukes

US General (Ret) Lee Butler speaks for a ban on nuclear weapons \#goodbyenukes

ICAN statement on UN International Day for the Total

Elimination of Nuclear Weapons

\section{9}

332

570

92,795

(Don't Want Your) Nuclear Umbrella

Martin Sheen \& John Dear - Oslo civil society forum 2013

\#ALittleMoreAction (To ban nuclear weapons)

Bombs No More

La prohibicion de las armas nucleares es mas urgente!

The urgency of banning nuclear weapons

Amazing Post-It mural to ban nuclear weapons

on behalf of ICAN Nosizwe Lise Baqwa at the High Level Meeting on Nuclear disarmament

ICAN Statement at the conference on the Humanitarian Impact of Nuclear Weapons https://www.youtube.com/ watch?v=xuxhPq40Lgg

https://www.youtube.com/ watch?v=SL-x5TDfeRk

https://www.youtube.com/ watch?v=al6X4GbAM1Y https://www.youtube.com/ watch?v=eH0EgOxdBT0 https://www.youtube.com/ watch? $\mathrm{v}=7$ ondKFdHKRs https://www.youtube.com/ watch?v=_enhRPZeAqc https://www.youtube.com/ watch?v=ASYKvWKtoJo https://www.youtube.com/ watch?v=g7ptF6zCALc

https://www.youtube.com/ watch?v=YqF4-UMJ-c8

https://www.youtube.com/ watch?v=Q7-gE25dEbg

https://www.youtube.com/ watch?v=R-A0TXE6A1E https://www.youtube.com/ watch?v=TOMYQPY9T6A\&t=82s

https://www.youtube.com/ watch? $\mathrm{v}=\mathrm{PBgF}-2 \mathrm{HK} 8 \mathrm{H} 0$ https://www.youtube.com/ watch?v=HuK9PvI6QYA https://www.youtube.com/ watch?v=iKh32VWCJWo https://www.youtube.com/ watch? $v=W t 4 C w 7$ rrqGE https://www.youtube.com/ watch?v=reZw23A3_dw

https://www.youtube.com/ watch?v=N4XMH9_1D8E https://www.youtube.com/ watch?v=c_c0ykvFMS0

https://www.youtube.com/ watch?v=OuDbRyw_Jh8 https://www.youtube.com/ watch?v=cykzBAPjh-s

https://www.youtube.com/ watch? $v=g$ LsThOaODVI

https://www.youtube.com/ watch?v=4cj90akGe0c

https://www.youtube.com/ watch?v=iumVR-FVyX8

https://www.youtube.com/ watch? $v=\mathrm{Nr} 3 \mathrm{ql}-\mathrm{h} 05 \mathrm{~d} 4$

https://www.youtube.com/ watch? $v=U A s p d 6 y X f N Y$

https://www.youtube.com/ watch?v=FlwHII-WBP0

https://www.youtube.com/ watch?v=uuuJ1B9o34Y

https://www.youtube.com/ watch?v=P_fTrDILkOo

https://www.youtube.com/ watch?v=ZjBd_GHvZOY

https://www.youtube.com/ watch?v=V7t6BmRzDS0 https://www.youtube.com/ watch?v=9t4A7MF5QuU 
135 are you ready to hit the gas?

Journée mondiale d'aboliton des armes nucléaires_francais. mov

Día de la Abolición Nuclear_Spanish

143 NUCLEAR ABOLITION DAY - ITALIANO

144 NUCLEAR ABOLITION DAY_Türk.mov

145 Nuclear Abolition Day_Svenskt.mov

146 Nuclear Abolition Day_ ICAN Norge.mov

147 Nuclear Abolition Day_Dutch.mov

148 Nuclear Abolition Day _ Deutsch

149 Nuclear Abolition Day

150 It is time. Ban nuclear weapons now!

151 Little More Action (to Ban nuclear weapons)_CAT.mov

152 A Little More Action (to ban nuclear weapons)_SP.mov

153 A Little More Action (to ban nuclear weapons)_ FR

154 A Little More Action (to ban nuclear weapons)_ITA

155 A Little More Action (to ban nuclear weapons)

International Campaign to Abolish Nuclear Weapons- Who We Are_ITA.mov

https://www.youtube.com/ watch? $v=\mathrm{k} 84 \mathrm{JLzC6BXw}$ https://www.youtube.com/ watch?v=PKmUezsHmsM https://www.youtube.com/ watch?v=-VqJ0O2Tuko

https://www.youtube.com/ watch? $v=$ cd-LOPsZasI

https://www.youtube.com/ watch?v=UIR7zq59vS8

https://www.youtube.com/ watch?v=AGPxX_qAqPI

https://www.youtube.com/ watch?v=N3oTxpHWKDw https://www.youtube.com/ watch?v=YoO_lja2xio

https://www.youtube.com/ watch?v=PX8BXJpUM3E https://www.youtube.com/ watch?v=84rRTzUnQ7I

https://www.youtube.com/ watch? $v=$ gny $1 \mathrm{LEgS} 1 \mathrm{tA}$ https://www.youtube.com/ watch?v=Hm1vLxV-Ycc https://www.youtube.com/ watch?v=cozT2cv5ZaU

https://www.youtube.com/ watch?v=PejrvjNR6JE

https://www.youtube.com/ watch?v=OjEod_FbMzl

https://www.youtube.com/ watch?v=oYqG5AHrHrY

https://www.youtube.com/ watch?v=6FcjFD7Tpds

https://www.youtube.com/ watch?v=gyBhx30 GHlc

https://www.youtube.com/ watch? $v=C D 7 Q o W H F j Q$ https://www.youtube.com/ watch? $v=\mathrm{e} 2 \mathrm{JW}$-aqKfvk

https://www.youtube.com/ watch?v=A5oDGkbzMjE

https://www.youtube.com/ watch?v=6XFZVDB3qml https://www.youtube.com/ watch?v=pM-73KRo4kY https://www.youtube.com/ watch? $v=r Y t E N D L O P p l$

https://www.youtube.com/ watch?v=-7YpM8KCGbU https://www.youtube.com/ watch?v=Fyqe7UoEhps 